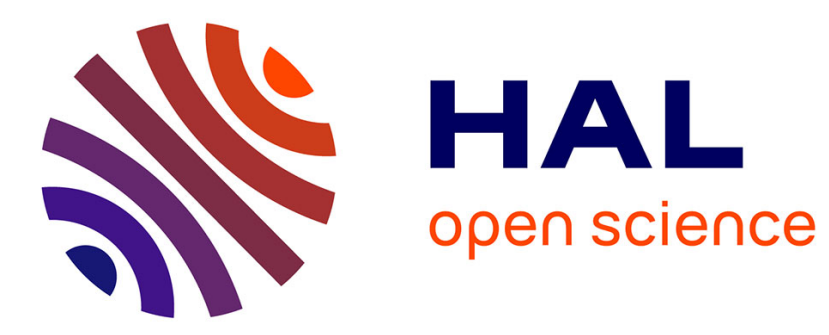

\title{
Nitride coating enhances endothelialization on biomedical NiTi shape memory alloy
}

Raluca Ion, Catalin Luculescu, Anisoara Cimpean, Philippe Marx, Doina-Margareta Gordin, Thierry Gloriant

\section{- To cite this version:}

Raluca Ion, Catalin Luculescu, Anisoara Cimpean, Philippe Marx, Doina-Margareta Gordin, et al.. Nitride coating enhances endothelialization on biomedical NiTi shape memory alloy. Materials Science and Engineering: C, 2016, 62, pp.686-691. 10.1016/j.msec.2016.02.031 . hal-01272661

\section{HAL Id: hal-01272661}

\section{https://hal-univ-rennes1.archives-ouvertes.fr/hal-01272661}

\author{
Submitted on 11 Feb 2016
}

HAL is a multi-disciplinary open access archive for the deposit and dissemination of scientific research documents, whether they are published or not. The documents may come from teaching and research institutions in France or abroad, or from public or private research centers.
L'archive ouverte pluridisciplinaire HAL, est destinée au dépôt et à la diffusion de documents scientifiques de niveau recherche, publiés ou non, émanant des établissements d'enseignement et de recherche français ou étrangers, des laboratoires publics ou privés. 


\title{
Nitride coating enhances endothelialization on biomedical
} NiTi shape memory alloy

\author{
Raluca Ion ${ }^{\mathrm{a}}$, Catalin Luculescu ${ }^{\mathrm{b}}$, Anisoara Cimpean ${ }^{\mathrm{a},{ }^{*} \text {, }}$ \\ Philippe Marx ${ }^{\mathrm{c}}$, Doina-Margareta Gordin ${ }^{\mathrm{d}}$, Thierry Gloriant ${ }^{\mathrm{d}}$
}

${ }^{a}$ University of Bucharest, Department of Biochemistry and Molecular Biology, 91-95 Spl. Independentei, 050095, Bucharest, Romania

${ }^{b}$ National Institute for Laser, Plasma and Radiation Physics, 409 Atomistilor, PO Box MG-36, 077125, Magurele-Bucharest, Romania

${ }^{c}$ AMF Company, Route de Quincy, 18120 Lury-sur-Arnon, France

${ }^{d}$ INSA Rennes, UMR CNRS 6226 ISCR, 20 avenue des Buttes de Coësmes, 35708 Rennes cedex 7, France

*Corresponding author:

E-mail address: anisoara.cimpean@bio.unibuc.ro

Tel.: +40 21 3181575/106; Fax: +40 21 3181575/ 102

University of Bucharest, Department of Biochemistry and Molecular Biology, 91-95 Spl. Independentei, 050095, Bucharest, Romania 


\section{ABSTRACT}

Surface nitriding was demonstrated to be an effective process for improving the biocompatibility of implantable devices. In this study, we investigated the benefits of nitriding the NiTi shape memory alloy for vascular stent applications. Results from cell experiments indicated that, compared to untreated NiTi, a superficial gas nitriding treatment enhanced the adhesion of human umbilical vein endothelial cells (HUVECs), cell spreading and proliferation. This investigation provides data to demonstrate the possibility of improving the rate of endothelialization on NiTi by means of nitride coating.

Keywords: NiTi alloy; surface nitriding; HUVEC, endothelialization 


\section{Introduction}

In the last two decades, the NiTi alloy (also known as $\mathrm{Nitinol}^{\mathrm{TM}}$ ) has been extensively used as vascular stent material due to its shape-memory, super-elastic properties and good biocompatibility. Moreover, the mechanical behavior of NiTi stented vessels is more similar with that of non-stented vessel areas, if compared with that of other metallic materials commonly used for biomedical devices, such as stainless steel $316 \mathrm{~L}$ and cobalt-chromium alloys [1]. However, NiTi shape memory alloy has several unfavorable clinical shortcomings when implanted in the human body that prevent it from being deemed as ideal material for stent devices. One concern with NiTi is related to the release of nickel ions which have very recently been shown to generate inhibition of the pathways associated with actin cytoskeleton, focal adhesion, energy metabolism, inflammation, and amino acid metabolism in endothelial cells [2]. Also, thrombotic complications frequently occur when NiTi alloy is used for vascular implants in small arteries [3]. Rapid re-endothelialization on the stent has been gradually considered as a feasible approach to prevent the occurrence of thrombosis, making the rate of endothelialization an important factor in characterizing the performance of a stent material. Consequently, a variety of strategies has been used in modifying NiTi to to provide the engineered devices with the desired properties such as increased corrosion resistance and improved endothelial cell coverage, which are important for fast endothelialization [4-7].

In the present study, the application of a nitride coating on NiTi alloy is proposed as an easy and economical surface treatment aimed to increase its biocompatibility. Based on reports in the literature, the nitride coating generally indicated a very good in vitro cell response [8-14]. However, there is limited knowledge about the effects of nitriding on NiTi-cell interaction. To 
verify whether nitride coating is able to enhance material endothelialization and to stably maintain functional characteristics of endothelial cells for long-term culture, human umbilical vein endothelial cells (HUVECs) were cultured on untreated and nitrided NiTi alloy, and the effects of both materials on the cellular responses, including cellular morphology, viability, proliferation and functional markers expression, were examined.

\section{Materials and methods}

\subsection{Materials and superficial gas nitriding treatment}

The NiTi alloy was provided by AMF Company (Lury-sur-Arnon, France) in sheet of $1 \mathrm{~mm}$ in thickness, with a composition of $55.8 \%$ wt of $\mathrm{Ni}$ and $44.2 \% \mathrm{wt}$ of Ti. From the sheet, disc-shaped samples (diameter: $13 \mathrm{~mm}$, thickness: $1 \mathrm{~mm}$ ) were cut. All samples were mechanically polished first on silicon carbide abrasive papers (up to 4000 grit) and then on polishing felt disc containing finely abrasive corundum powder $(1 \mu \mathrm{m})$. They were finally ultrasonically cleaned in acetone, thoroughly washed with ethanol and dried in air. Part of the samples was superficially treated by gas nitriding. For that, samples were first introduced in a silica tube and a highvacuum pumping $\left(10^{-6} \mathrm{mbar}\right)$ was realized. Then, one atmosphere of high purity nitrogen gas $\left(\mathrm{N}_{2}>99.99 \%\right)$ was introduced in the tube. The gas nitriding treatment of the samples was carried out at $950^{\circ} \mathrm{C}$ for $2 \mathrm{~h}$ in a conventional furnace. Once the gas nitriding treatment was realized, nitrided NiTi samples (nNiTi) were observed by atomic force microscopy (AFM, CSM Instrument) and characterized by $\mathrm{X}$-ray diffraction (XRD, $\mathrm{Cu} \mathrm{K} \alpha$ radiation, Philips). 


\subsection{Cell culture}

Human umbilical vein endothelial cells, purchased from American Type Culture Collection (ATCC) were maintained in F-12K Medium (Kaighn's Modification of Ham's F-12 Medium) supplemented with 10\% fetal bovine serum (Gibco), 1\% penicillin - streptomycin (Gibco) and $30 \mu \mathrm{g} \cdot \mathrm{mL}^{-1}$ endothelial cell growth supplement (Sigma-Aldrich Co.) at $37^{\circ} \mathrm{C}$ in $5 \% \mathrm{CO}_{2}$ atmosphere. HUVECs (passages 3-7) were used in this study. For the experiments, HUVECs were seeded onto the samples at a density of $10^{4}$ cells $\cdot \mathrm{cm}^{-2}$ and maintained for up to 5 days in standard culture conditions. Prior to cell seeding, samples were sterilized by soaking in $70 \%$ ethanol for $30 \mathrm{~min}$. Then, the samples were rinsed twice for $30 \mathrm{~min}$ in sterile-filtered MilliQ water, air dried and exposed to ultraviolet light in a sterile tissue culture hood, for 30 minutes on each side.

\subsection{Assessment of cell adhesion and spreading}

HUVEC cell attachment and spreading on each sample were examined using Scanning electron microscopy (SEM). Cells that had been incubated on substrates for $2 \mathrm{~h}$ were processed for SEM visualization according to the procedure previously presented [15]. Cell imaging investigation was conducted on a field emission scanning electron microscope (Inspect S Electron Scanning Microscope, FEI Company). The attached cells in three randomly selected fields were captured and the cell area was measured using ImageJ software.

\subsection{Fluorescence staining of actin and vinculin}


Cell morphology was assessed by double fluorescent staining of vinculin and actin at $2 \mathrm{~h}$ and 24 h post-seeding. Briefly, at the end of each incubation time, the cells were washed with PBS (phosphate buffered saline), fixed with 4\% paraformaldehyde in PBS and permeabilized with 0.1\% Triton X-100 in PBS. For immunostaining, cells were blocked in PBS containing 2\% bovine serum albumin (BSA) and then incubated with anti-vinculin antibody (Santa Cruz Biotechnology, dilution 1:50 in 1.2\% BSA in PBS) for $2 \mathrm{~h}$ at room temperature, washed again with PBS and incubated for $1 \mathrm{~h}$ with Alexa-Fluor 546- conjugated specific secondary antibody (Invitrogen, dilution 1:200 in 1.2\% BSA in PBS). For double-staining, Alexa Fluor 488 Phalloidin $\left(20 \mu \mathrm{g} \cdot \mathrm{mL}^{-1}\right.$, Invitrogen) was added, and the samples were incubated at room temperature for $15 \mathrm{~min}$. The labeled cells were washed three times with PBS and examined by using Olympus IX71 microscope equipped for epifluorescence. The images were captured by means of Cell $\mathrm{F}$ image acquiring system.

\subsection{Assay of cell viability and proliferation}

Cell proliferation was quantified by MTT [3-(4,5-dimethylthiazol-2-yl)-2,5-diphenyltetrazolium bromide)] colorimetric assay at 1-, 3- and 5- days post-seeding. Briefly, cell cultures were incubated with MTT solution $\left(1 \mathrm{mg} \cdot \mathrm{mL}^{-1}\right.$ in serum free culture medium) for $3 \mathrm{~h}$ at $37^{\circ} \mathrm{C}$. Then, the MTT solution was decanted and formazan crystals were solubilized with dimethyl sulfoxide. Absorbance of the dye was measured at a wavelength of $550 \mathrm{~nm}$ and recorded using a microplate reader (Thermo Scientific Appliskan). 
The LIVE/DEAD Viability/Cytotoxicity Assay Kit (L-3224, Invitrogen) was also used to image and assess cellular viability on the tested substrates. After 1-, 3- and 5- days of culture, samples were rinsed with PBS and then stained with a calcein acetoxymethyl ester (calcein AM): ethidium homodimer 1 (EthD-1) solution $(2 \mathrm{M}: 4 \mu \mathrm{M})$ for $10 \mathrm{~min}$ in the dark, at room temperature. Following incubation, the cell populated materials were rinsed with PBS and, subsequently, visualized using an inverted fluorescence microscope Olympus IX71. Images of representative microscopic fields were captured by means of Cell $\mathrm{F}$ image acquiring system.

\subsection{Evaluation of functional markers expression}

HUVECs were seeded on the samples at a density of 10000 cells $\cdot \mathrm{cm}^{-2}$ and cultured for 5 days. Immunofluorescence staining was performed to detect the expression of endothelial-specific markers in endothelial cells grown on the samples. Briefly, the samples were rinsed with PBS, fixed with $4 \%$ paraformaldehyde, permeabilized with $0.1 \%$ Triton X-100 in PBS, and blocked in PBS containing 2\% BSA. The samples were then incubated with mouse anti-human von Willebrand factor (vWf) monoclonal antibody (Santa Cruz Biotechnology) and rabbit antihuman endothelial nitric oxide synthase (eNOS) polyclonal antibody (Santa Cruz Biotechnology) in PBS containing 1.2\% BSA. After washes with PBS, they were further incubated with Alexa Fluor 546-conjugated goat anti-mouse IgG antibody (Invitrogen) and Alexa Fluor 488conjugated goat anti-rabbit IgG antibody (Invitrogen), respectively, in PBS containing 1.2\% BSA, followed by washing with PBS. A $2 \mu \mathrm{g} \cdot \mathrm{mL}^{-1}$ DAPI (4'6-diamidino-2- phenylindole) solution was used to stain cell nuclei. Fluorescent images were taken with an Olympus IX71 inverted microscope. 


\subsection{Statistical analysis}

Statistical analysis was performed with GraphPad Prism software using one-way ANOVA with Bonferroni's multiple comparison tests. Triplicate samples were used in MTT assay to ensure the reproducibility of the results. The data are presented as means \pm SD (standard deviation). The pvalues $<0.05$ were considered to be statistically significant.

\section{Results and discussion}

\subsection{Surface observations}

A photograph of the untreated $\mathrm{NiTi}$ and the nNiTi surfaces has been taken and is presented in Fig. 1. A clear difference of the superficial aspect can be observed. The untreated NiTi presents the classical metallic grey color of the alloy (A) while the nitrided NiTi presents a golden yellow color (B). This golden yellow color is typically that which one observes when the face-centered cubic $\delta$-TiN nitride (space group: Fm3 m) was formed on the surface. This observation is in good agreement with the literature since whatever the superficial nitriding treatment used on NiTi (gas nitriding, laser gas nitriding...), this TiN nitride constitutes the main component of the coating obtained $[16,17]$. The formation of the $\delta$-TiN nitride on surface was confirmed by X-ray diffraction in this study. Indeed, the XRD profile presented in Fig. 2 clearly displays the different peaks related to the TiN nitride and also those related to the NiTi B2 structure (space group: Pm3 m) and the $\mathrm{Ti}_{2} \mathrm{Ni}$ (space group: $\mathrm{Fd} 3 \mathrm{~m}$ ) intermetallic compounds. The presence of this 
intermediate $\mathrm{Ti}_{2} \mathrm{Ni}$ phase between $\mathrm{TiN}$ and NiTi was also mentioned in literature [18]. The fact that the main peak of the B2 NiTi substrate was detected by XRD indicates that the thickness of the nitride layer does not exceed a few micrometers. This is in accordance with a recent work, in which similar gas nitriding parameters were used and around $3 \mu \mathrm{m}$ of nitride thickness was obtained [19].

The roughness on the NiTi surfaces (untreated and nitrided) was evaluated by AFM. For that, tapping mode was used in air with a silicon tip. To evaluate the roughness of both surfaces, 10 measurements were obtained from $100 \times 100 \mu \mathrm{m}$ AFM scans taken in different zone of each surface. Examples of AFM maps for untreated and nitrided NiTi surfaces are presented in Fig. 3A and Fig. 3B, respectively. From the AFM maps, uniform roughness was obtained from both surfaces. The roughness value, Ra, was measured to be $57 \mathrm{~nm} \pm 6 \mathrm{~nm}$ for the untreated NiTi alloy and $163 \pm 9 \mathrm{~nm}$ for the nitrided NiTi alloy, respectively. Thus, the nitriding treatment carried out within the framework of this study induces a roughness three times higher in comparison with the untreated surface.

\subsection{Endothelial cell response}

Previous studies have shown that surface nitriding could enhance the attachment and spreading of different types of cells on a variety of materials [20-27]. The improvement of cell affinity was ascribed to the change in surface topography and increased adsorbtion of serum proteins maintaining their native configuration on the coated surfaces. However, there are also published reports that demonstrated equivalent adhesion and spreading of cells on nitrided and unmodified 
materials [28-30]. In the present study, initial HUVECs adhesion and spreading on nitrided NiTi (nNiTi) as compared to un-treated surface were studied by SEM (Fig. 4A).

Although cell density was similar on both samples, the spreading area appeared to be higher on the nNiTi. Indeed, quantification of cell spreading area by ImageJ software (Fig. 4B) at $2 \mathrm{~h}$ post-seeding showed that HUVECs spreading on nNiTi covered a median area of $988 \mu \mathrm{m}^{2}$, whereas HUVEC cells spreading on NiTi covered a median area of $691 \mu \mathrm{m}^{2}$. Thus, these experiments demonstrate that surface nitriding is competent to promote cell spreading. It is known that strong adhesion of cells to substrate develops over time as the cells spread and more focal adhesions are formed. Furthermore, focal adhesions activate signaling pathways which control cell function and architecture [31]. Better cell adhesion and spreading result in higher activation of intracellular signaling cascades through integrin coupled to the actin cytoskeleton. A major protein of focal adhesions and a key player in the regulation of cell adhesion is vinculin [32]. Therefore, vinculin provides a valuable detection system for focal adhesion sites by means of specific antibody detection. In the present study, focal adhesion formation was analyzed by immunocytochemistry using a monoclonal antibody against vinculin, whereas the organization of actin cytoskeleton was visualized by incubation with Alexa Fluor 488 Phalloidin (Fig. 5). Obvious focal adhesions marked by dot-like vinculin were detected in the HUVECs cultured on both alloys at $2 \mathrm{~h}$ post-seeding. Endothelial cells maintained on NiTi revealed good cell adhesion. However, increased cell spreading and more focal contacts have been observed on the nitrided sample. At this time point, high resolution fluorescence images showed a circumferential localization of actin filaments near the cell membrane and also some parallel oriented actin filaments. After $24 \mathrm{~h}$ of culture, fluorescence analysis revealed typical appearance of endothelial cells with well-expressed stress fibers orientated parallel to one another and to the long axis of 
the cell. Staining for vinculin revealed that HUVECs formed many focal adhesions, which were present in peripheral region of the cells. These results demonstrate that nitriding is able to stimulate both endothelial cell spreading and focal adhesion formation on NiTi substrates.

The effect of nitride coating on endothelial cells proliferation was further investigated by MTT viability assay after incubation for 1-, 3- and 5- days. Fig. 6 shows the proliferation of HUVECs on the surface of NiTi and nNiTi. As it can be seen, the number of viable metabolically active endothelial cells continuously increased on both substrates. At the end of incubation time, the level of cell proliferation on nNiTi alloy and control surface was significantly higher than those found after 1 and 3 days of culture. More importantly, HUVECs on nNiTi surfaces exhibited significantly increased proliferation compared with those on control NiTi after 1 and 3 days of culture. By day 5, nNiTi still had a higher number of metabolically active cells, but the differences were no longer statistically significant. Our data point to the positive role that nitride coating can play in promoting endothelial cell coverage of vascular stents.

Furthermore, cells on the NiTi substrates were also stained with a solution containing calcein AM and ethidium homodimer and imaged using fluorescence microscopy. Live cells fluoresce green due to ester hydrolysis of calcein AM to calcein, while dead cells fluoresce red due to DNA binding of ethidium homodimer in cells with compromised nuclear membranes. After staining, highly viable cells were observed on both substrates (Fig. 7). Moreover, microscopic observations confirmed the results of MTT assay showing higher cell density on nitrided samples.

A possible explanation for the observed differences in cell spreading and growth between the two analyzed samples could be the changes of surface roughness and corrosion resistance 
induced by the surface treatment. As seen from AFM results, 2.85 times the amount of nanometer surface roughness was measured for nitrided compared with the conventional nitinol. The growth of HUVECs was previously shown to increase on nano-scale rough surfaces [33]. Thus, increased surface roughness of biomaterial surfaces even at 10-10(2) nm scale has been demonstrated to enhance the adhesion and growth of HUVECs.

The differences in the endothelial cell proliferation on the nitrided and control nitinol samples might also result from the differences in corrosion resistance. Previous cell culture evaluations indicated that nickel-based alloys did not affect cellular viability or morphology [34]. However, nickel-based alloys released corrosion products which decreased cellular proliferation. It was hypothesized that this decrease was due to an interference of the released metal ions with the cellular energy metabolism. Given the fact that nitride coating has been demonstrated to effectively prevent release of $\mathrm{Ni}$ ions [2], application of TiN coating could explain the improvement of the proliferation rate of endothelial cells on nitinol substrate.

A clear beneficial effect of nitriding treatment on cell behavior is already acknowledged in literature. Nitrogen plasma-implanted NiTi alloy has been shown to exhibit the highest amount of cell proliferation in long term cultures of osteoblasts derived from calvarial bones of mice when compared to untreated NiTi, medical grade stainless steel and Ti-6Al-4V [35]. Moreover, the release of nickel ions was found to be significantly reduced compared with the untreated NiTi. Biocompatibility enhancement of the porous nitinol ${ }^{\mathrm{TM}}$ was also reported after in-situ nitriding [36], higher densities of bone marrow stromal cells being achieved on in-situ nitrided samples than on unmodified nitinol ${ }^{\mathrm{TM}}$. Furthermore, the porous NiTi samples were implanted into rabbits' bones to investigate their osseointegration capability and the results revealed that the in-situ nitrided porous NiTi is much more effective in promoting bone regeneration than the 
porous NiTi without surface modifications. More recently, Yang et al. [30] used vacuum filtered arc plasma deposition technique to generate a nitride coating on nitinol and investigated endothelial cell adhesion, morphology and viability on both alloys. Although initial cell adhesion as well as proliferation were higher on nitrided samples, the differences were not statistically significant. In addition, the serum protein layer adsorbed on bare NiTi alloy was found to be qualitatively and quantitatively almost the same as the one on TiN-coated NiTi alloy. Further on, the same authors [2] showed that, overtime, released nickel ions inhibited endothelial cell function at molecular level, whereas TiN coating improved endothelial cell function. Specifically, TiN coating promoted actin cytoskeleton and focal adhesion formation, increased energy metabolism, enhanced regulation of inflammation, and promoted amino acid metabolism.

The long-term success of implanted cardiovascular NiTi devices is dependent upon the ability of the material to resist corrosion, to support the growth, migration and function of endothelial cells. Von Willebrand factor and eNOS are often used as vascular endothelial cell markers to examine endothelial cell function.

The expression and cellular localization of $\mathrm{vWf}$ and eNOS were investigated by immunofluorescence at 1-, 3- and 5- days post-seeding. As shown in Fig. 8, the cells grown on nitrided samples had similar vWf and eNOS expression to the cells grown on untreated NiTi. Taken together, these results suggest that surface modified NiTi promotes endothelial cell adhesion and proliferation with functional $\mathrm{vWf}$ and eNOS marker expression.

\section{Conclusions}


In the present work we have investigated the effect of surface nitriding on the endothelialization of NiTi shape memory alloy. Our results indicate that this approach can be used to enhance the adhesion and proliferation of HUVECs on NiTi surface. Moreover, we report similar expression of vWf and eNOS functional markers on both substrates. Although the presented results clearly demonstrate an increase in NiTi biocompatibility by surface nitriding, the benefits of this modification for in vivo condition remain to be determined.

\section{Acknowledgment}

This study was financially supported by research grant from the Romanian Ministry of National Education, CNCS-UEFISCDI (project PN-II-ID-20-RO-FR-2014) and by the French ANR (project ANR-13-IS09-0008-01). 


\section{References}

[1] S.A. Shabalovskaya, On the nature of the biocompatibility and on medical applications of NiTi shape memory and superelastic alloys, Biomed. Mater. Eng. 6 (1996) 267-289.

[2] D. Yang, X. Lü, Y. Hong, T. Xi, D. Zhang, The molecular mechanism for effects of TiN coating on NiTi alloy on endothelial cell function, Biomaterials 35 (2014) 6195-6205.

[3] M. Shayan, Y. Chun, An overview of thin film nitinol endovascular devices, Acta Biomater. $21(2015) 20-34$.

[4] S.D. Plant, D.M. Grant, L. Leach, Behaviour of human endothelial cells on surface modified NiTi alloy, Biomaterials 26 (2005) 5359-5367.

[5] J.M. Schmehl, C. Harder, H.P. Wendel, C.D. Claussen, G. Tepe, Silicon carbide coating of nitinol stents to increase antithrombogenic properties and reduce nickel release, Cardiovasc. Revasc. Med. 9 (2008) 255-262.

[6] Y. Shen, G. Wang, L. Chen, H. Li, P. Yu, M. Bai, Q. Zhang, J. Lee, Q. Yu, Investigation of surface endothelialization on biomedical nitinol (NiTi) alloy: Effects of surface micropatterning combined with plasma nanocoatings, Acta Biomater. 5 (2009) 3593-3604.

[7] W. Shen, K. Cai, Z. Yang, Y. Yan, W. Yang, P. Liu, Improved endothelialization of NiTi alloy by VEGF functionalized nanocoating, Colloids Surf. B Biointerfaces 94 (2012) 347- 353. [8] M. Annunziata, L. Guida, L. Perillo, R. Aversa, I. Passaro, A. Oliva, Biological response of human bone marrow stromal cells to sandblasted titanium nitride-coated implant surfaces, $\mathrm{J}$. Mater. Sci. Mater. Med. 19 (2008) 3585-3591. 
[9] M. Annunziata, A. Oliva, M.A. Basile, M. Giordano, N. Mazzola, A. Rizzo, A. Lanza, L. Guida, The effects of titanium nitride-coating on the topographic and biological features of TPS implant surfaces, J. Dent. 39 (2011) 720-728.

[10] S. Durual, F. Pernet, P. Rieder, M. Mekki, M. Cattani-Lorente, H.W.A. Wiskott, Titanium nitride oxide coating on rough titanium stimulates the proliferation of human primary osteoblasts, Clin. Oral Implants Res. 22 (2011) 552-559.

[11] V.H. Pham, S.H. Jun, H.E. Kim, Y.H. Koh, Deposition of titanium nitride (TiN) on Co-Cr and their potential application as vascular stent, Appl. Surf. Sci. 258 (2012) 2864-2868.

[12] D.M. Gordin, T. Gloriant, V. Chane-Pane, D. Busardo, V. Mitran, D. Hoche, C. Vasilescu, S.I. Drob, A. Cimpean, Surface characterization and biocompatibility of titanium alloys implanted with nitrogen by Hardion+ technology, J. Mater. Sci. Mater. Med. 23 (2012) $2953-$ 2966.

[13] D.M. Gordin, D. Busardo, A. Cimpean, C. Vasilescu, D. Höche, S.I. Drob, V. Mitran, M. Cornen, T. Gloriant, Design of a nitrogen-implanted titanium-based superelastic alloy with optimized properties for biomedical applications, Mater. Sci. Eng. C Mater. Biol. Appl. 33 (2013) 4173-4182.

[14] R. Ion, C. Vasilescu, P. Drob, E. Vasilescu, A. Cimpean, I. Drob, D.M. Gordin, T. Gloriant, Long-term corrosion performances and cytocompatibility of nitrided $\mathrm{Ti}$ and $\mathrm{Ti}-6 \mathrm{Al}-4 \mathrm{~V}$ alloy in severe functional conditions, Mater. Corros. 65 (2014) 593-604.

[15] R. Ion, S. Vizireanu, C.E. Stancu, C. Luculescu, A. Cimpean, Gh. Dinescu, Surface plasma functionalization influences macrophage behavior on carbon nanowalls, Mater. Sci. Eng. C Mater. Biol. Appl. 48 (2015) 118-125. 
[16] S.K. Wu, H.C. Lin, C.Y. Lee, Gas nitriding of an equiatomic TiNi shape memory alloy. Part I: Nitriding parameters and microstructure characterization, Surf. Coat. Technol. 113 (1999) 1724.

[17] Z.D. Cui, H.C. Man, X.J. Yang, Characterization of the laser gas nitrided surface of NiTi shape memory alloy, Appl. Surf. Sci. 208-209 (2003) 388-393.

[18] G. Zorn, R. Adadi, R. Brener, V.A. Yakovlev, I. Gotman, E.Y. Gutmanas, C.N. Sukeni, Tailoring the surface of NiTi alloy using PIRAC nitriding followed by anodization and phosphonate monolayer deposition, Chem. Mater. 20 (2008) 5368-5374.

[19] H. Li, Z. Cui, Z. Li, S. Zhu, X. Yang, Surface modification by gas nitriding for improving cavitation erosion resistance of CP-Ti, Appl. Surf. Sci. 298 (2014) 164-170.

[20] B. Groessner-Schreiber, A. Neubert, W.D. Müller, M. Hopp, M. Griepentrog, K.P. Lange, Fibroblast growth on surface-modified dental implants: An in vitro study, J. Biomed. Mater. Res. A 64 (2003) 591-599.

[21] H.H. Huang, C.H. Hsu, S.J. Pan, J.L. He, C.C. Chen, T.L. Lee, Corrosion and cell adhesion behavior of TiN-coated and ion-nitrided titanium for dental applications, Appl. Surf. Sci. 244 (2005) 252-256.

[22] B. Grössner-Schreiber, M. Herzog, J. Hedderich, A. Dück, M. Hannig, M. Griepentrog, Focal adhesion contact formation by fibroblasts cultured on surface-modified dental implants: An in vitro study, Clin. Oral Implants Res. 17 (2006) 736-745.

[23] C.C. Chien, K.T. Liu, J.G. Duh, K.W. Chang, K.H. Chung, Effect of nitride film coatings on cell compatibility, Dent. Mater. 24 (2008) 986-993.

[24] H.W. Jang, H.L. Lee, J.Y. Ha, K.H. Kim, T.Y. Kwon, Surface characteristics and osteoblast cell response on TiN and TiAlN-coated Ti implant, Biomed. Eng. Lett. 1 (2011) 99-107. 
[25] G. Kaklamani, J. Bowen, N. Mehrban, H. Dong, L.M. Grover, A. Stamboulis, Active screen plasma nitriding enhances cell attachment to polymer surfaces, Appl. Surf. Sci. 273 (2013) 787798.

[26] G. Kaklamani, N. Mehrban, J. Bowen, H. Dong, L. Grover, A. Stamboulis, Nitrogen plasma surface modification enhances cellular compatibility of aluminosilicate glass, Mater. Lett. 111 (2013) 225-229.

[27] E.P. Ferraz, J.C. Sa, P.T. de Oliveira, C. Jr. Alves, M.M. Beloti, A.L. Rosa, The effect of plasma-nitrided titanium surfaces on osteoblastic cell adhesion, proliferation, and differentiation, J. Biomed. Mater. Res. A 102 (2014) 991-998.

[28] W.C. Clem, V.V. Konovalov, S. Chowdhury, Y.K. Vohra, S.A. Catledge, S.L. Bellis, Mesenchymal stem cell adhesion and spreading on microwave plasma-nitrided titanium alloy, J. Biomed. Mater. Res. A 76 (2006) 279-287.

[29] C.Y. Li, S.Y. Gao, T. Terashita, T. Shimokawa, H. Kawahara, S. Matsuda, N. Kobayashi, In vitro assays for adhesion and migration of osteoblastic cells (Saos-2) on titanium surfaces, Cell Tissue Res. 324 (2006) 369-375.

[30] D. Yang, X. Lü, Y. Hong, T. Xi, D. Zhang, The molecular mechanism of mediation of adsorbed serum proteins to endothelial cells adhesion and growth on biomaterials, Biomaterials $34(2013) 5747-5758$

[31] M. Bigerelle, K. Anselme. Bootstrap analysis of the relation between initial adhesive events and long-term cellular functions of human osteoblasts cultured on biocompatible metallic substrates, Acta Biomater. 1 (2005) 499-510.

[32] K. Anselme, Osteoblast adhesion on biomaterials, Biomaterials 21 (2000) 667-681. 
[33] T.W. Chung, D.Z. Liu, S.Y. Wang, S.S. Wang, Enhancement of the growth of human endothelial cells by surface roughness at nanometer scale, Biomaterials 24 (2003) 4655-4661. [34] J.D. Bumgardner, J. Doeller, L.C. Lucas, Effect of nickel-based dental casting alloys on fibroblast metabolism and ultrastructural organization, J. Biomed. Mater. Res. 29 (1995) 611617.

[35] K.W.K. Yeung, R.W.Y. Poon, P.K. Chu, C.Y. Chung, X.Y. Liu, W.W. Lu, D. Chan, S.C.W. Chan, K.D.K. Luk, K.M.C. Cheung, Surface mechanical properties, corrosion resistance, and cytocompatibility of nitrogen plasma-implanted nickel-titanium alloys: a comparative study with commonly used medical grade materials, J. Biomed. Mater. Res. A 82A (2007) 403-414.

[36] H. Li, B. Yuan, Y. Gao, C.Y. Chung, M. Zhu, Remarkable biocompatibility enhancement of porous NiTi alloys by a new surface modification approach: in-situ nitriding and in vitro and in vivo evaluation, J. Biomed. Mater. Res. A 99A (2011) 544-553. 


\section{Figures}

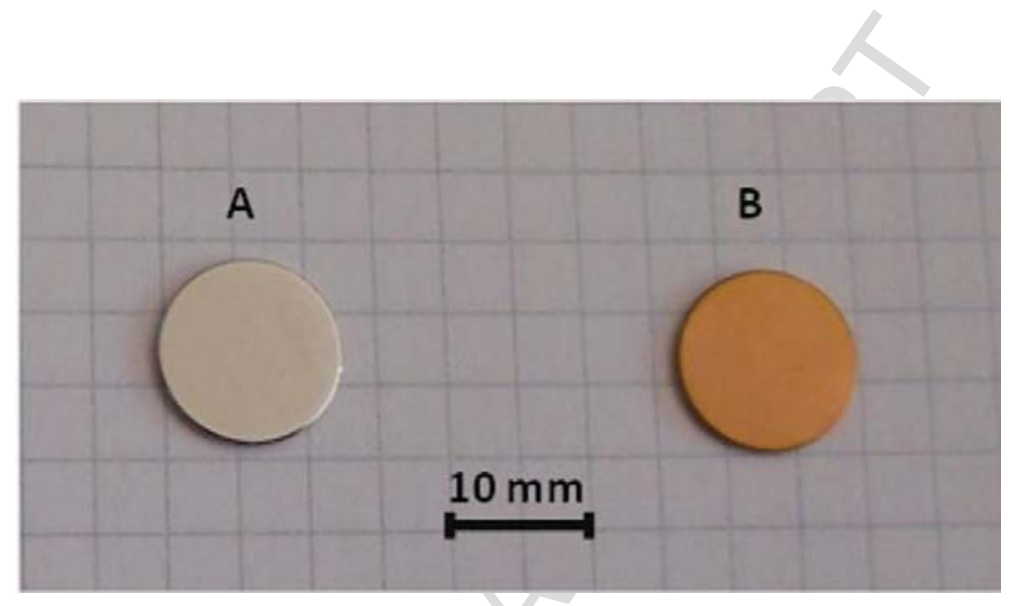

Fig. 1. Photograph of the untreated NiTi surface (A) and the nitrided NiTi surface (B). 


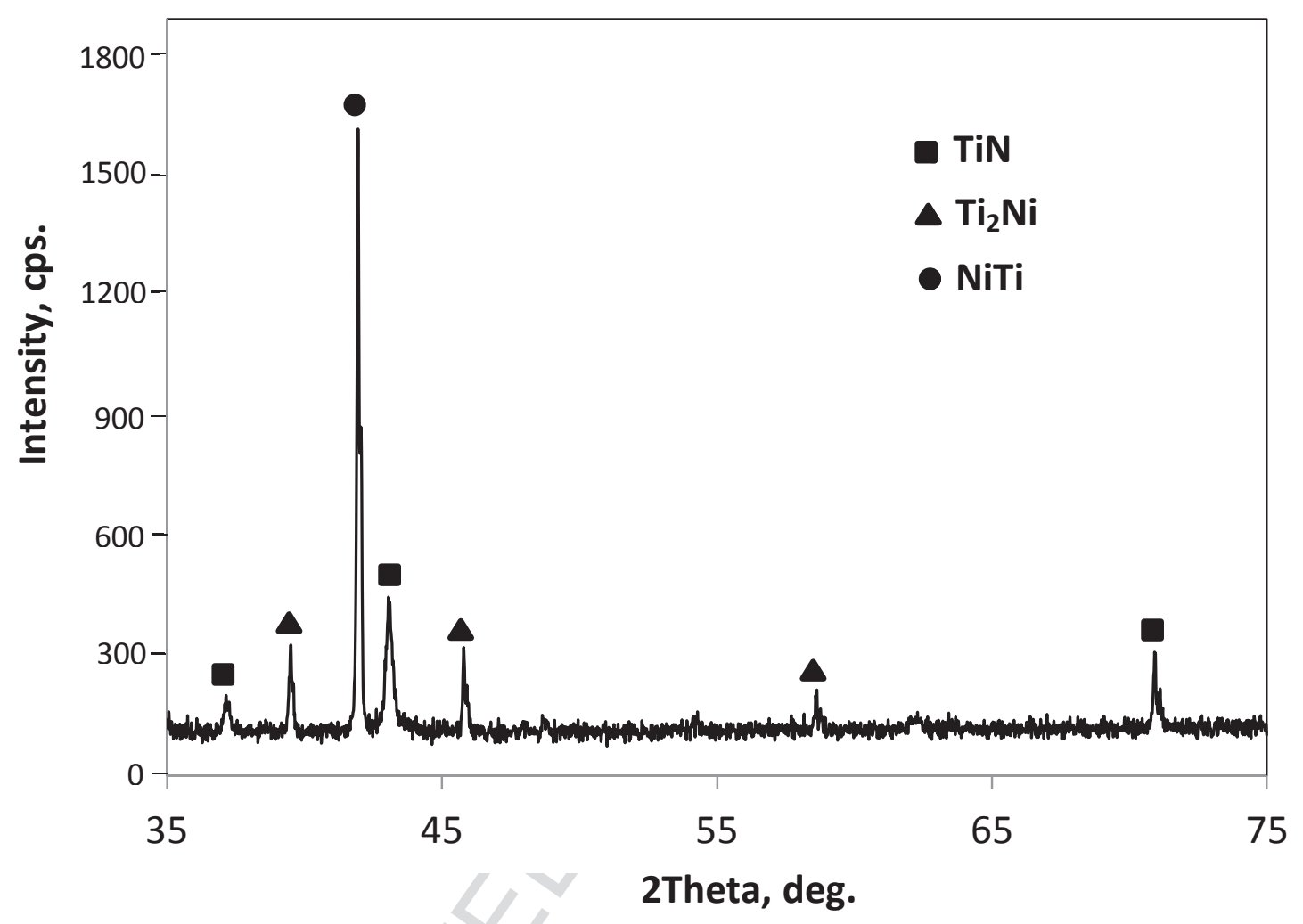

Fig. 2. XRD profile of the nitrided NiTi alloy. 

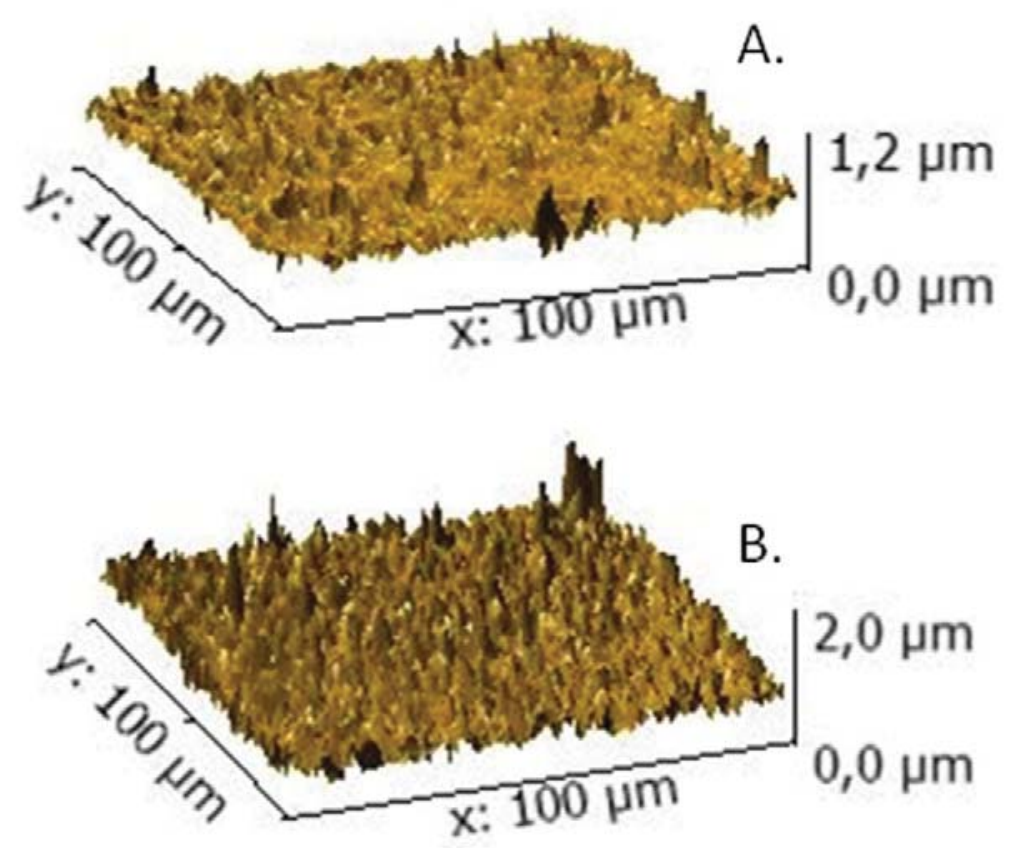

Fig. 3. AFM maps: (A) untreated NiTi surface and (B) nitrided NiTi surface. 
A.
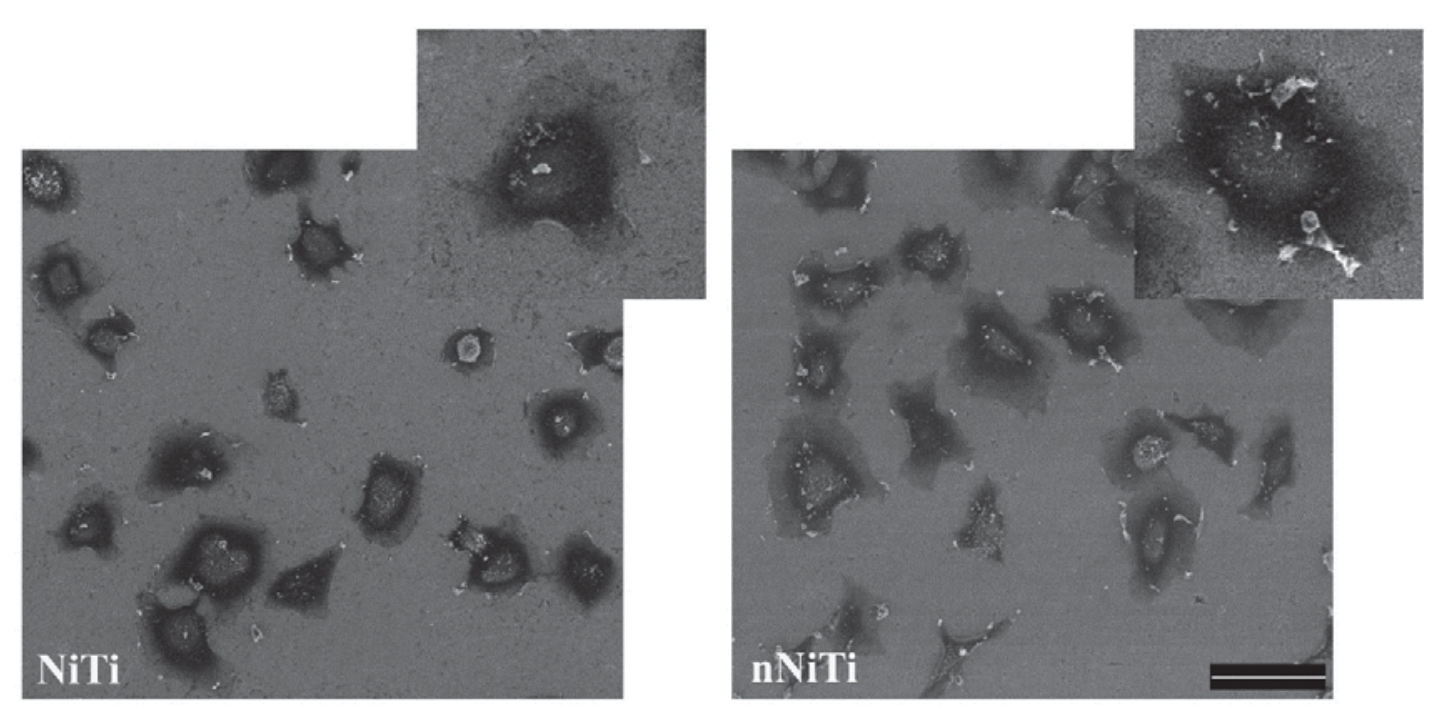

B.

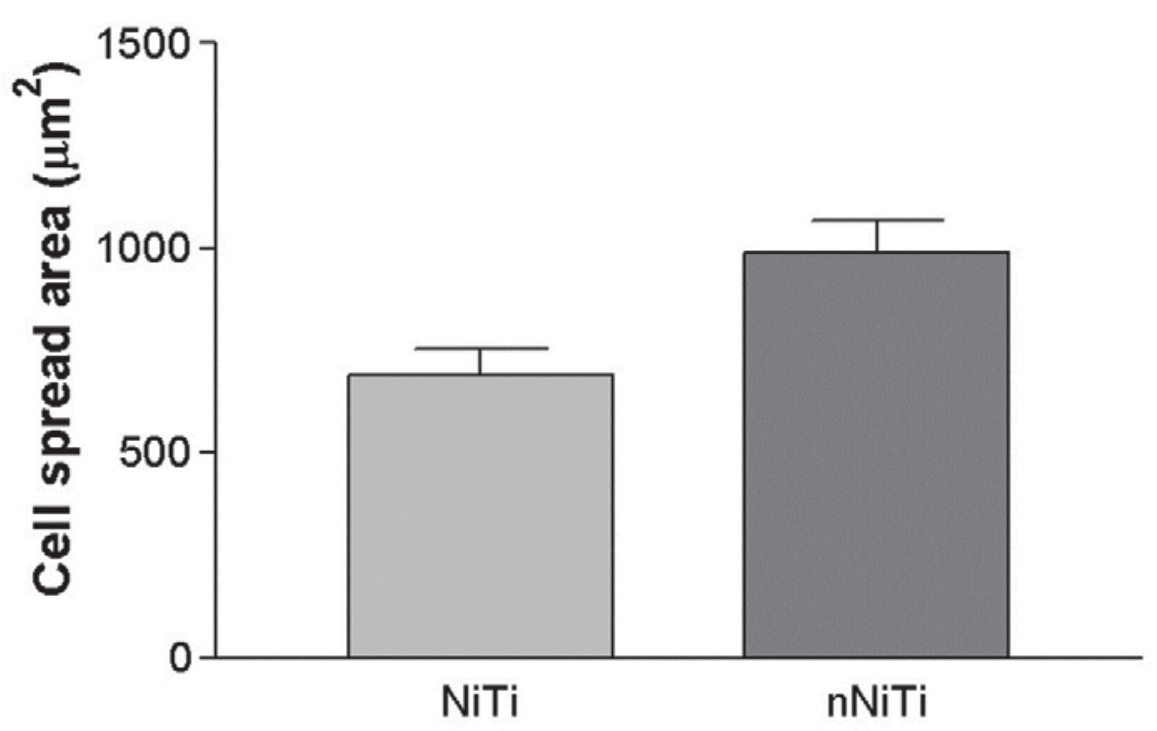

Fig. 4. A. SEM images of HUVECs adhered to NiTi and nNiTi for $2 \mathrm{~h}$. Scale bar represents 50 $\mu \mathrm{m}$. B. Spreading area of HUVEC cells plated on NiTi and nNiTi for $2 \mathrm{~h}$. 

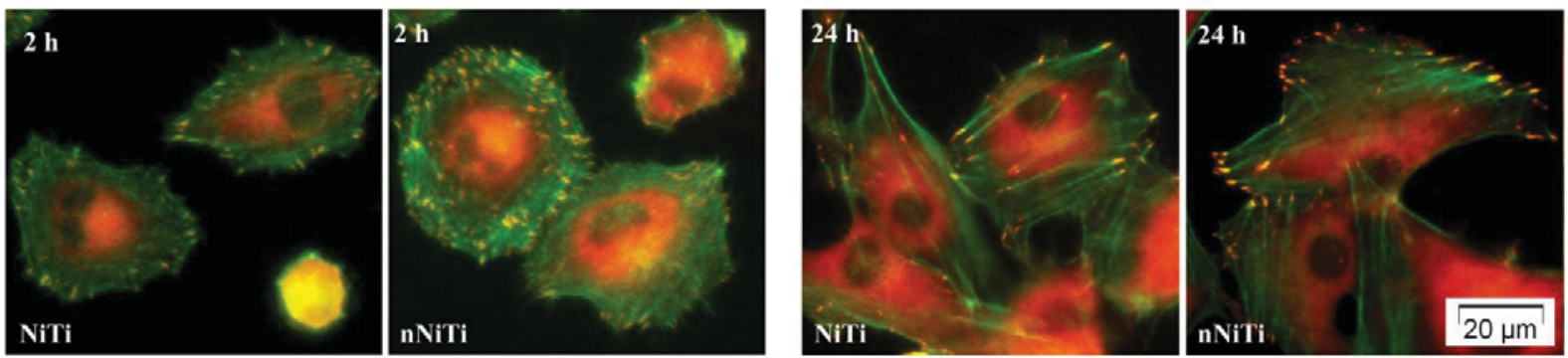

Fig. 5. Merged fluorescence images of actin filaments (green) and vinculin (red) in HUVEC cells grown on NiTi and nNiTi surfaces. 


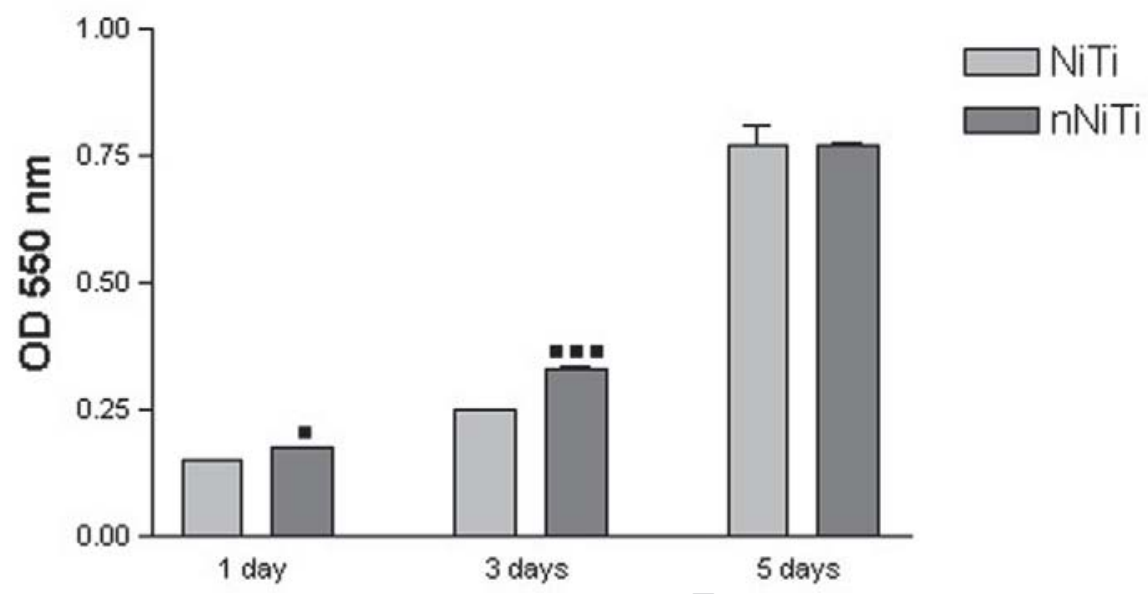

Fig. 6. Viability/proliferation of HUVEC cells cultured in direct contact with analyzed samples for 1, 3 and 5 days as determined by MTT assay. Data analysis was based on mean $\pm \operatorname{SD}(n=3)$. $\cdot \mathrm{p}<0.05$ versus control at 1 day post-seeding; $\cdot \cdot \mathrm{p}<0.001$ versus corresponding control at 3 days post-seeding. 


\section{ACCEPTED MANUSCRIPT}
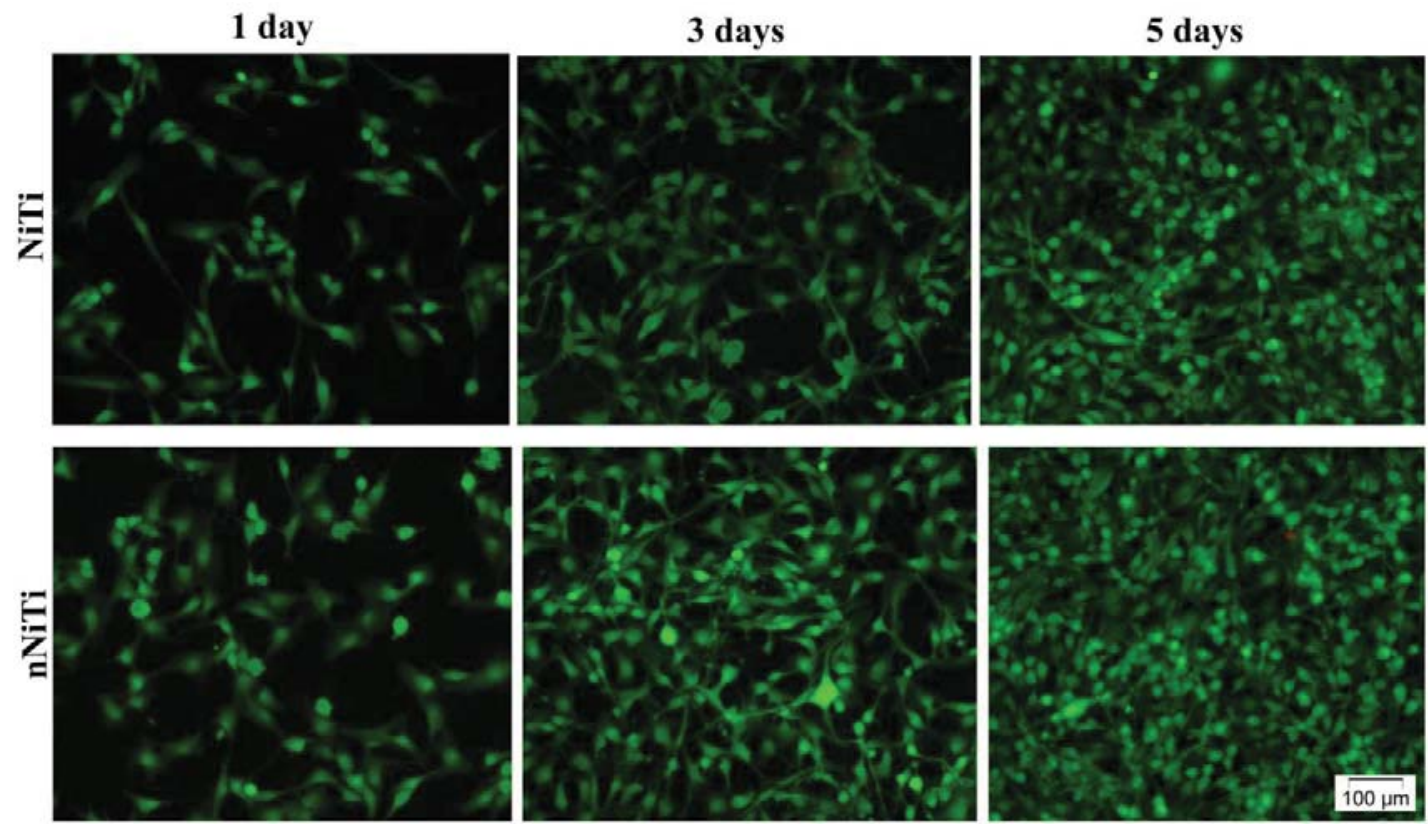

Fig. 7. Live/Dead images of HUVEC cells at 1, 3 and 5 days post-seeding. Green = live cells; Red $=$ dead cells 


\section{ACCEPTED MANUSCRIPT}
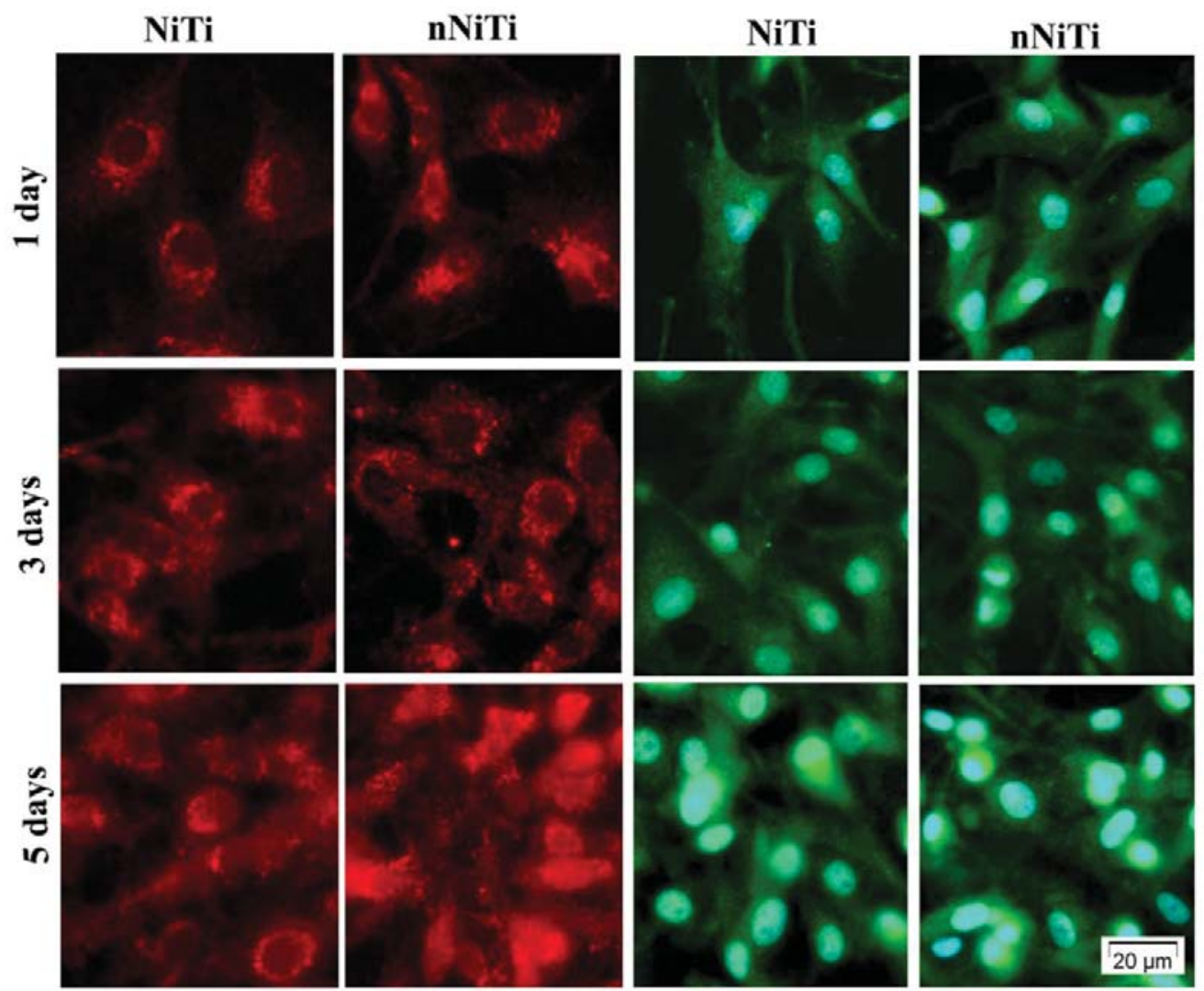

Fig. 8. Fluorescence images showing distribution of vWf (red) and eNOS (green) in HUVEC cells cultured for 1, 3 and 5 days on NiTi and nNiTi. The nuclei are stained in blue with DAPI. 
Graphical abstract
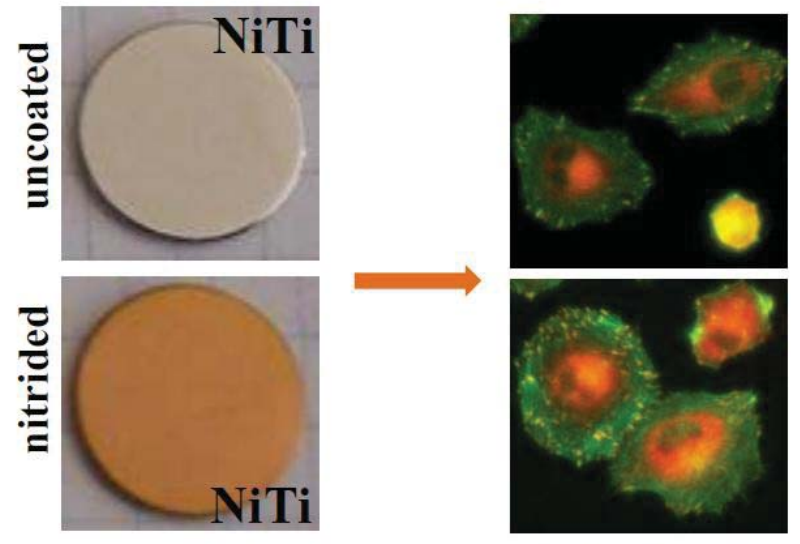

Cell proliferation

Cell adhesion

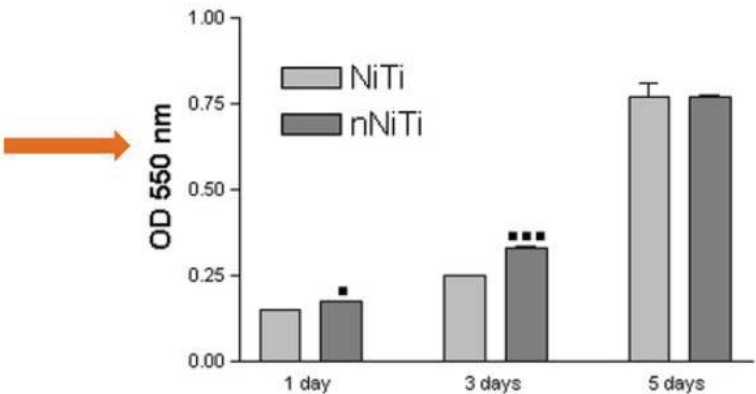




\section{Highlights}

- Gas nitriding process of NiTi is competent to promote cell spreading.

- Surface nitriding of $\mathrm{NiTi}$ is able to stimulate focal adhesion formation and cell proliferation.

- Similar expression pattern of vWf and eNOS was exhibited by bare and nitrided NiTi.

- Gas nitriding treatment of NiTi shows promise for a better in vivo endothelialization. 